\title{
Motivation to learn and social support determine employability among vocational high school students
}

\author{
Fatwa Tentama ${ }^{1}$, Subardjo ${ }^{2}$, Muhamad Hasan Abdillah ${ }^{3}$ \\ ${ }^{1,3}$ Faculty of Psychology, Universitas Ahmad Dahlan, Indonesia \\ ${ }^{2}$ Faculty of Law, Universitas Ahmad Dahlan, Indonesia
}

\begin{tabular}{l} 
Article Info \\
\hline Article history: \\
Received Feb 10, 2019 \\
Revised Apr 2, 2019 \\
Accepted Apr 15, 2019 \\
\hline
\end{tabular}

Keywords:

Employability

Motivation to learn

Social support

\begin{abstract}
One of the factors that influence the level of employability is the motivation to learn and social support. This study aims to determine the effect of motivation to learn and social support on student employability. The participants in this study were 255 students of class XII in State Vocational High School 1 Kalasan Yogyakarta, obtained through random cluster sampling. The data collection was carried out by using an employability scale, motivation to learn scale and social support scale. The data analysis used in this study was multiple linear regression analysis. Our data analysis shows that motivation to learn and social support have a very significant effect on employability, seen through the $\mathrm{F}$ test that obtained a score of 44.798 and a significance level $(\mathrm{p})$ of $0.000(\mathrm{p}<0.01)$. In other words, the level of employability could be predicted based on students' level of motivation to learn and social support.
\end{abstract}

Copyright $@ 2019$ Institute of Advanced Engineering and Science All rights reserved.

\section{Corresponding Author:}

Fatwa Tentama,

Faculty of Psychology, Universitas Ahmad Dahlan,

Kapas street 9, Semaki, Umbulharjo, Yogyakarta.

Email: fatwa.tentama@psy.uad.ac.id

\section{INTRODUCTION}

Employability is one of the criteria for measuring the workability of individuals with the needs of the workforce [1]. Employability of individuals can also affect individuals to be able to manage their work careers [2]. It is also used in various contexts concerning numerous meanings [3]. Employability has been used to describe the objectives of economic strategies in the workplace at the national, regional and local level [4]. According to Gamboa, Gracia, Ripoll, and Peiró [5] employability is one's perception on his or her own opportunity to get a job of his/her choice, considering that these opportunities will depend on individual characteristics and behavior as well as contextual factors.

Jameson [6] emphasizes the importance of developing student employability on job seeking [7]. Employability is related to individuals in job seeking in a way that individuals with employability will try to improve themselves to get a job [8]. According to Fugate, Kinicki, and Ashforth [9] employability is very important for every individual because employability can increase the likelihood of individuals to get jobs. Employability helps individuals to understand the things needed to get a job [10]. The function of employability is to ensure that individuals have confidence in their abilities to get a job according to their goals [11].

Employability is a problem that often arises concerning job seeking, and low employability is a barrier for individuals to enter the workforce [7, 12, 13]. Benabou and Tirole [11] argue that lack of employability limits the actions and ambitions of individuals to enter the workforce. Low employability can make it difficult for individuals to get jobs [14]. 
Motivation to learn is believed to have the ability to predict the level of employability of an individual [15]. According to Thijssen, Van der Heijden, and Rocco [16] motivation to learn is a significant factor that influences the level of individual employability. In line with the opinion of Wittekind, Raeder, and Grote [17] which states that low level of motivation to learn affects level of employability. Motivation to learn acts as the drive to increase employability by setting learning goals, standard results to be obtained, and assessment of learning outcomes [18].

Motivation to learn is a belief held by individuals about their ability to learn, values related to an activity, and the level of interest they have in learning activities [19]. Schunk, Pintrich, and Meece [20] define motivation to learn as a complex concept involving various internal forces, such as instincts, impulses, habits, needs, and goals, often used to explain successes or failures in learning tasks. Motivation to learn can be defined as goal actualization of individual motives in certain situations where individuals emphasize readiness or willingness to change [21]. Meanwhile according to Ye [22] motivation to learn is the driving force for conducting learning activities, promoting spontaneous efforts and maintaining learning activities without orders from others.

Individuals will not necessarily have employability with no available social support. This is because social support is needed to have better employability [23]. Social support is a psychological resource that enhances the employability of individuals to deal with stress and the possibility of not getting a job [24]. The primary role of social networking is to provide social support for the members inside. Additionally, in the context of employability, the availability of social support can increase individual employability level [25]. Some researchers have shown that social support is an essential resource for individuals because it can help individuals to develop [26], achieve career plans, and improve employability [27].

Social support is defined as an understanding from other people that the person is loved, cared for, appreciated, valued, and also regarded as part of a communication network with mutual needs [28]. DiMatteo [29] defines social support as support or assistance that comes from other people (e.g., family, friends, or coworkers). Social support refers to comfort, care, appreciation, or assistance received by someone from another person or group [30]. Social support is the help we receive from other significant people such as family, friends, or coworkers in the form of emotional, information, material or behavioral support [31].

The purpose of this study was to determine the effect of motivation to learn and social support on employability in vocational students. As an implication, we hope that this study could help inform schools to pay attention to several factors that can improve the employability of vocational students.

\section{RESEARCH METHOD}

The participants in this study were 225 students of class XII in State Vocational High School 1 Kalasan, Sleman, Yogyakarta. The selection of research participants was randomized with cluster sampling technique.

This study measured the variables using three Likert Scales, namely the employability scale, motivation to learn scale, and social support scale. Employability is measured using the employability scale which refers to aspects of employability according to Pool and Sewell [7], namely: skills, knowledge, understanding, and personal attributes. The motivation to learn scale by Sardiman [32], measures the following aspects of motivation: diligence in doing school assignments, resilience in facing difficulties, showing interest in various problems, preference in independent work, getting bored quickly in routine tasks, ability to stick with his/her opinion, strongly holds his/her belief, and likes to solve social problems. Meanwhile, the social support scale by Smet [33], measured these aspects of social support: emotional attention, information, instrumental, and positive affirmation.

\subsection{Instrument validity and reliability}

On the employability scale, with 61 subjects, the result of the reliability coefficient was 0.821 . The corrected item-total correlation index moves from 0.289 to 0.510 . Twenty items were considered valid and reliable. On the motivation to learn the scale, with 61 test subjects, the reliability coefficient was 0.920 . The corrected item-total correlation index moves from 0.258 to 0.711 . Valid and reliable items that were used for research were 33 items. On the social support scale, with 61 test subjects, the result of the reliability coefficient was 0.857 . The corrected item-total correlation index moves from 0.297 to 0.695 . Valid and reliable items that were used for research were 20 items.

\subsection{Data analysis}

The method for data analysis used was parametric method. Data analysis was performed using SPSS 17.0 for Windows, through multiple regression technique, a statistical analysis technique to 
determine the effect of two independent variables (motivation to learn and social support) on one dependent variable (employability).

\section{RESULTS AND DISCUSSION}

\subsection{Normality test}

Table 1 presents the results of the normality testing for all variables: Employability with a K-SZ score coefficient $=0.934$ and $\mathrm{p}=0.347$; motivation to learn with a K-SZ score coefficient $=1.345$ and $\mathrm{p}=$ 0.054 ; and social support with a K-SZ score coefficient $=1.034$ with $p=0.235$. This indicates that there is no difference between the sample and population score distribution. In other words, the sample is able to represent the population.

Table 1. Normality test

\begin{tabular}{cccc}
\hline Variable & K-SZ score & Sig. & Notes \\
\hline Employability & 0.934 & 0.347 & Normal \\
Motivation to learn & 1.345 & 0.054 & Normal \\
Social support & 1.034 & 0.235 & Normal \\
\hline
\end{tabular}

\subsection{Linearity test}

Table 2 presents the results of the linearity test that an $\mathrm{F}$ was obtained on motivation to learn towards employability with a score of 28.817 and a significance level $(p)$ of 0.000 . This suggests that the data is linear - in other words, there is a line that connects motivation to learn with employability. Meanwhile, the linearity test of social support towards employability results with an $F$ that scores 72.474 and a significance level $(p)$ of 0.000 which indicates a linear connection between social support and employability.

Table 2. Linearity test

\begin{tabular}{|c|c|c|c|c|}
\hline Variable & $\mathrm{F}$ & Significance & Criteria & Notes \\
\hline Motivation to learn & 28.817 & 0.000 & $\mathrm{P}<0.05$ & Linear \\
\hline Social Support & 72.474 & 0.000 & $\mathrm{P}<0.05$ & Linear \\
\hline
\end{tabular}

\subsection{Multicollinearity test}

Table 3 presents based on the analysis that motivation to learn and social support each had a VIF value $=1.086(\mathrm{VIF}<10)$ and tolerance $0.921=($ tolerance $>0.1)$, indicating that there is no multicollinearity between motivation to learn and social support.

Table 3. Multicollinearity test

\begin{tabular}{cccc}
\hline Variable & Tolerance & VIF & Notes \\
\hline Motivation to learn & 0.921 & 1.086 & No multicollinearity \\
Social Support & 0.921 & 1.086 & No multicollinearity \\
\hline
\end{tabular}

\subsection{Multiple regression test}

Table 4 desribes the multiple regression analysis. It shows $F=44.798$ with a significance level $(p)$ of $0.000(<0.01)$. The result means that motivation to learn and social support have a very significant effect on employability in vocational high school students. The magnitude of the contribution of the effect of motivation to learn and social support on employability is indicated by the Adjusted R Square value $=0.281$, meaning that the influence of motivation to learn and social support contributes $28.1 \%$ while the remaining $71.9 \%$ is influenced by other factors beyond the variables studied.

Table 4. Multiple regression test result

\begin{tabular}{cccccc}
\hline Variable & Adjusted R Square & F & Sig & Criteria & Notes \\
\hline $\begin{array}{c}\text { Motivation to learn and Social } \\
\text { Support on Employability }\end{array}$ & 0.281 & 44.798 & 0.000 & $\mathrm{P}<0.01$ & $\begin{array}{c}\text { Both variables } \\
\text { have a very } \\
\text { significant effect } \\
\text { on employability }\end{array}$ \\
\hline
\end{tabular}




\subsection{Analysis of relationships between variables}

Based on Table 5, the results of the regression analysis show that the magnitude of the effect of motivation to learn on employability was $(t)=3.452$ with a significance level of $0.001(p>0.01)$. It is indicating that there is a very significant effect of motivation to learn on employability in vocational high school students. Meanwhile, the regression analysis of social support on employability obtained $(t)=7.486$ with a significance level of 0.00 . The result means that there is a very significant effect of social support on employability in vocational high school students.

Table 5. Analysis of relationships between variables

\begin{tabular}{|c|c|c|c|c|}
\hline Variable & $\mathrm{t}$ & Sig & Criteria & Notes \\
\hline Motivation to learn on employability & 3.452 & 0.001 & $\mathrm{p}<0.01$ & There is a very significant effect \\
\hline Social support on employability & 7.486 & 0.000 & $\mathrm{p}<0.01$ & There is a very significant effect \\
\hline
\end{tabular}

The regression analysis results of the two independent variables, namely: motivation to learn and social support on students' employability, show that motivation to learn and social support simultaneously affect student employability. Based on these results, the first hypothesis claiming that employability can be predicted based on motivation to learn and social support is accepted. The two independent variables contribute $28.1 \%$ to employability, while the remaining $71.9 \%$ is influenced by other factors outside the scope of this study.

Various empirical studies have been carried out to determine the factors that influence employability, including employability activities [34], self-efficacy and employability culture [35], proactive personality, boundaryless mindset, identity awareness, social networks, social support, self-esteem, job search and re-employment [36], positive emotions and commitment [37], involvement and life satisfaction [38], health and well-being [39]. Partially, the results of this study indicate that motivation to learn contributes to employability by $7.4 \%$ and the contribution of social support to employability is $22.4 \%$. The effect of social support on employability is more dominant than motivation to learn on employability students in State Vocational High School 1 Kalasan.

In the second hypothesis, we found that motivation to learn could also significantly influence student employability, indicating that the hypothesis is accepted. The results are in line with the findings of Raemdonck, Beausaert, Fröhlich, Kochoian, and Meurant [40] who also support previous research and broadened the understanding of the mechanism by which low motivation to learn is an obstacle to increasing employability. The results of the Wiers-Jenssen study [41] also found that the impact that resulted from a high motivation to learn was the increase in individual employability.

According to Tymon [42] employability can be developed by increasing motivation to learn, in a broader sense, it will benefit individuals to engage with more open skill development activities which leads to more successful developments. By having the positive motivation to learn, individuals can achieve a systematic self-awareness to develop better employability [43].

In the third hypothesis proposed, it was found that there was an influence of social support on the employability of students, indicating that the hypothesis is accepted. The results obtained are supported by the assumed theory and also some other similar research results such as Eby, Butts, and Lockwood's research [44] which showed that individuals with more extensive social support network are believed to have higher employability. Social support can facilitate the development of career identity, provide support for learning, and convey relevant career knowledge [45]. In line with empirical studies conducted by McArdle, Waters, Briscoe, and Hall [36] showed that there was a bond between social support and employability.

The implications of this study can provide insight and awareness to students, parents, and teachers. This research shows that motivation to learn and social support, especially those from parents and teachers, have a role in preparing students to gain knowledge, skills, and good understanding in the school environment. Parents and teachers must be able to create a positive environment so that they can provide motivation and social support for students. Thus students will be better prepared to get a job and quickly adapt to their work after graduating from Vocational High School. The results of this study can also be used as a reference for developing training modules to solve problems for Vocational High School students, especially training to improve employability of Vocational students through training in motivation to learn and social support.

Int. J. Eval. \& Res. Educ. Vol. 8, No. 2, June 2019: 237 - 242 


\section{CONCLUSION}

One of the factors that influence the level of employability is the motivation to learn and social support. The research found that there is a very significant effect of motivation to learn and social support simultaneously to the employability among students in State Vocational High School 1 Kalasan. Motivation to learn also determines employability among students as well as social support.

\section{ACKNOWLEDGEMENTS}

The authors would like to thank the Faculty of Psychology of Universitas Ahmad Dahlan and State Vocational High School 1 Kalasan, Sleman, Yogyakarta for the technical assistance in this study. The authors also thank all participating students, teachers, school administrators, and other individuals for their efforts, assistance, and involvement in this research.

\section{REFERENCES}

[1] Sasmito, A. P., "Work readiness of software engineering student in Batu City," Education and Humanities Research, vol 116, pp. 67-70, 2017.

[2] Hess, N., Jepsen, D. M., \& Dries, N., "Career and employer change in the age of the "boundaryless' career," Journal of Vocational Behavior, vol 81(2), pp. 280-288, 2012.

[3] McQuaid, R. and Lindsay, C., "The 'employability gap': Long-term unemployment and barriers to work in buoyant labour markets," Environment and Planning C: Government and Policy, vol 20(4), pp. 613-628, 2002.

[4] UN., Recommendations of the high level panel of the youth employment network. United Nations, New York, 2001.

[5] Gamboa, J., Gracia, F., Ripoll, P., \& Peiró, J. M., "La empleabilidad y la iniciativa personal como antecedentes de la satisfacción laboral," Instituto Valenciano de Investigaciones Económicas, vol 1, pp. 1-26, 2007.

[6] Jameson, SM., "A case study of international hospitality students development of employability skills," Tourism and Hospitality Research, pp. 57-59, 2008.

[7] Dacre Pool, L., and Sewell, P., "The key to employability: Developing a practical model of graduate employability," Journal of Education and Training, vol 49(4), pp. 277-289, 2007.

[8] McQuaid, R. W. And Lindsay, C., "The concept of employability", Urban Studies, vol 42(2), pp. 197-219, 2005.

[9] Fugate, M., Kinicki, A., \& Ashforth, B., "Employability: A psycho-social construct, its dimensions, and applications," Journal of Vocational Behavior, vol 65(1), pp. 14-38, 2004.

[10] Brewer, L., Enhancing youth employability: What? Why? and How? Guide to core workskills. International Labour Organization, Geneva, 2013.

[11] Benabou, R. and Tirole, J., "Self-confidence and personal motivation," The Quarterly Journal of Economics, vol 117(3), pp. 871-915, 2002.

[12] Norman, M. and Hyland, T., "The role of confidence in lifelong learning", Educational Studies, vol 29(2/3), pp. 261-272, 2003

[13] Yorke, M. and Knight, P., "Evidence-informed pedagogy and the enhancement of student employability," Teaching in Higher Education, vol/issue: 12(2), pp. 157-170, 2007.

[14] Ronnås, P. and Shamchiyeva, L., Employment diagnostic analysis: Maluku, Indonesia. International Labour Organization, Geneva, 2011.

[15] Tammaro, AM., "Recognition and quality assurance in LIS: New approaches for lifelong learning in Europe," Performance Measurement and Metrics, vol 6(2), pp. 67-79, 2005.

[16] Thijssen, JG., Van der Heijden, B., \& Rocco, T., "Toward the employability-link model: current employment transition to future employment perspectives," Human Resource Development Review, vol 7(2), pp. 165-183, 2008.

[17] Wittekind, A., Raeder, S., \& Grote, G., "A longitudinal study of determinants of perceived employability," Journal of Organizational Behavior, vol 31(4), pp. 566-586, 2009.

[18] Fry, H., Ketteridge, S., \& Marshall, S., A handbook for teaching and learning in higher education: Enhancing academic practice. Routledge, New York, 2015.

[19] Kramarski, B. and Michalsky, R., "Investigating preservice teachers' professional growth in self-regulated learning environments," Journal of Educational Psychology, vol 101, pp. 161-175, 2009.

[20] Schunk, D., Pintrich, PR., \& Meece, JL., Motivation in education: Theory, research, and application. Merrill/Prentice Hall, Upper Saddle River, 2008.

[21] Long, R., The Rob Long omnibus edition of better behavior. Routledge, New York, 2007.

[22] Ye, B., "A study on the definition of motivation to learn and related theories," Education in Pintung University, vol 16, pp. 285-293, 2013.

[23] Clarke, M. and Patrickson, M., "The new covenant of employability," Employee Relations, vol 30(2), pp. 121-141, 2008.

[24] Van der Heijden, B., Kümmerling, A., Van Dam, K., Van der Schoot, E., Estryn-Béhar, M., \& Hasselhorn, HM., "The impact of social support upon intention to leave among female nurses in Europe: Secondary analysis of data from the NEXT survey," International Journal of Nursing Studies, vol 47(4), pp. 434-445, 2010.

[25] Adraki, PK., Allotey, SS., \& Yeboah, F., "Social networks and employability in the Tamale Metropolis of the Northern Region, of Ghana," Journal of Agricultural Economics and Rural Development, vol 4(1), pp. 357-364, 2018. 
[26] Masdonati, J., Massoudi, K., \& Rossier, J., "Effectiveness of career counseling and the impact of the working alliance," Journal of Career Development, vol 36(2), pp. 183-203, 2009.

[27] Brown, DJ., Cober, RT., Kane, K., Levy, PE., \& Shalhoop, J., "Proactive personality and the successful job search: A field investigation with college graduates," Journal of Applied Psychology, vol 91(3), pp. 717-726, 2006.

[28] Taylor, S., Health psychology. Mc Graw Hill, New York, 2009.

[29] DiMatteo, MR., "Social support and patient adherence to medical treatment: A meta-analysis," Health Psychology, vol 23(2), pp. 207-218, 2004.

[30] Sarafino, EP., Health psychology: Biopsychosocial interactions. John Willey \& Sons Inc, United States, 2008.

[31] Thoits, PA., "Stress and health: Major findings and policy implications," Journal of Health and Social Behavior, vol 5(1), pp. 41-53, 2010.

[32] Sardiman, AM., Interaksi dan motivasi belajar mengajar. Raja Grafindo Persada, Jakarta, 2001.

[33] Smet, B., Psikologi kesehatan. Grasindo, Jakarta, 1994.

[34] Van Dam, K., "Antecedents and consequences of employability orientation," European Journal of Work and Organizational Psychology, vol 13(1), pp. 29-51, 2004.

[35] Nauta, A., Van Vianen, A., Van der Heijden, B., Van Dam, K., \& Willemsen, M., "Understanding the factors that promote employability orientation: The impact of employability culture, career satisfaction, and role breadth self-efficacy," Journal of Occupational and Organizational Psychology, vol 82(2), pp. 233-251, 2009.

[36] McArdle, S., Waters, L., Briscoe, JP., \& Hall, DT., "Employability during unemployment: Adaptability, career identity and human and social capital," Journal of Vocational Behavior, vol 71(2), pp. 247-264, 2007.

[37] Fugate, M. and Kinicki, AJ., "A dispositional approach to employability: Development of a measure and test of implications for employee reactions to organizational change," Journal of Occupational and Organizational Psychology, vol 81(3), pp. 503-527, 2008.

[38] De Cuyper, N., Bernhard-Oettel, C., Bernston, E., De Witte, H., \& Alarco, B., "Employability and employees' well-being: Mediation by job insecurity," Applied Psychology, vol 57(3), pp. 488-509, 2008.

[39] Berntson, E. and Marklund, S., "The relationship between perceived employability and subsequent health," Work \& Stress, vol 21(3), pp. 279-292, 2007.

[40] Raemdonck, I., Beausaert, S., Fröhlich, D., Kochoian, N., \& Meurant, C., "Aging workers' learning and employability," Springer International Publishing Switzerland, pp. 163-184, 2015.

[41] Wiers-Jenssen, J., "Background and employability of mobile vs. non-mobile students," Tertiary Education and Management, vol 17(2), pp. 79-100, 2011.

[42] Tymon, A., "The student perspective on employability," Studies in Higher Education, vol 38(6), pp. 841-856, 2013.

[43] Melnic, AS. and Botez, N., "Academic motivation to learn," Economy Transdisciplinarity Cognition, vol 17(2), pp. 56-62, 2014.

[44] Eby, LT., Butts, M., \& Lockwood, A., "Predictors of success in the era of the boundaryless career," Journal of Organizational Behavior, vol 24(6), pp. 689-708, 2003.

[45] Parker, P., Arthur, M., \& Inkson, K., "Career communities: A preliminary exploration of memberdefined career support structures," Journal of Organizational Behavior, vol 25(4), pp. 489-514, 2004.

Int. J. Eval. \& Res. Educ. Vol. 8, No. 2, June 2019: 237 - 242 